\title{
Association between Teat condition score and Udder health status in dairy bovines
}

\author{
Vikas Singh $^{1}$, V. K. Singh ${ }^{2}$, Pranab Doley ${ }^{3}$ and Ajit Singh ${ }^{4}$ \\ ${ }^{1}$ Department of Livestock Production Management \\ ${ }^{2}$ Department of Animal nutritionCollege of Veterinary Science and Animal Husbandry, N.D.U.A.T., Kumarganj, \\ Faizabad, Uttar Pradesh- 224229 (India)
}

\begin{abstract}
The present research work was undertaken to assess the association between teat condition score (TCS) and udder health status of dairy bovines.Total 50 cows (HF cross) and 50 buffaloes (murrah type) were selected randomly and observed for 120 days at fortnightly intervals. The animals were divided into 3 groups i.e. Normal, Less-severe and Severe on the basis of TCS.The overall SCS in both cows and buffaloes was significantly $(P<0.05)$ highest in Severe group $(5.91 \pm 0.02$ and $6.09 \pm 0.35)$ followed by Less severe $(5.15 \pm 0.18$ and5.85 \pm 0.09$)$ and Normal $(4.18 \pm 0.21$ and $5.31 \pm 0.112)$. Teat condition significantly affects the udder health status of dairy bovines.
\end{abstract}

Keywords: Somatic cell score, Teat condition score, udder health status,

\section{Introduction}

The physical condition of the bovine teat is an indicator of the quality of the environment, the milking management and milking system used on a dairy herd and it can also be used as an indicator for the risk of intramammary infections. The teats of the dairy cow are affected by the milking process (Mein et al., 2001), the general environmental conditions on the farm (Hillertonet al., 2002) and by any agent applied to the teats (Hemlinget al., 2002). Poor teat condition can reduce milk yields and increase milking times. Teat condition scoring is a valuable tool that has virtually no cost (Reinemann 2001).Quick action to find the cause of poor teat condition will reduce somatic cell counts and clinical mastitis, saving time and treatment costs (Taylor, 2006). According to Hillerton (2005) teats may vary in colour within cow and certainly within a herd according to breed and to breeding. Haghkhahet al. (2009) found a significant correlation between teat condition and somatic cell count and reported that injured (severe) teat have significantly higher SCC in comparison to normal teat whereas Bhutto (2010) had not found significant correlation between teat condition and SCC. There is not any ultimate conclusion drawn to establish the relation between teat condition and udder health status. Therefore this study was carried to establish the relation between teat condition and udder health status.

\section{Materials and methods}

This study was carried out in the area under subtropical zone of Indo-Gangetic plane. A total of 50 lactating dairy cows (HF cross cows) and 50 buffaloes (Murrah type) of second parity available at the Instructional Livestock farm complex in the college of Veterinary Science and Animal Husbandry, N.D.U.A.T. KumarganjFaizabad (U. P.) and in the small dairy farms present in the surrounding villages were selected and observed for 4 months to study the association among Teat condition score and udder health. The animals in farm and field condition were maintained under loose housing system and the stanchion system respectively. The data collected at fortnightly intervals were, the Teat Condition Score (TCS), and Somatic cell count of milk. Milk sample was collected directly from the animal during milking to assess the somatic cell count of milk.Teat conditionscoring adopted by Hillerton (2005) was use to assess the teat condition. For this teat location along with any abnormal condition was observed. The scoring was categorised as follows:

I. Teat skin: normal or discoloured (indicating either red or blue tinged)

II. Teat skin: normal or cracked (indicating chapped, bitten or cut)

III. Teats: normal or swollen (indicating swelling, hardness or wedging of teat end)

IV. Teats end: smooth, rough or very rough (indicating severity of hyperkeratosis at the teat end)

To study the relationship between teat condition and udder health status (SCS), teat condition scores of animals were classified in to three groups as follows:

\begin{tabular}{|l|l|l|}
\hline Group & Condition & Teat condition score \\
\hline I & Normal & up to 1 \\
\hline II & Less severe & More than 1 and up to 2 \\
\hline III & Severe & More than 2 and up to 3 \\
\hline
\end{tabular}


The udder health status was determined by somatic cell count (SCC) of milk. Somatic cell count in milk was assessed for each animal in the laboratory immediately after collection in fortnightly intervals. To determine the SCC in milk0.01 ml of milk was smeared in 1 square $\mathrm{cm}$. area on a glass slide, dried with gentle heat and dissolved fat with xylene for 2 to 5 minutes after that fixed the smear with $40 \%$ alcohol for 5 minutes and stain with methylene blue. After one minute, wash the stained slide with distilled water and dry the smear and milk somatic cells was counted in oil immersion microscope. Average cell number is multiplied by microscopic factor (5 lakh) to get the total number of leucocytes per ml of milk sample. After that fortnightly test day observation of SCC was log-transformed into the fortnightly test day observation SCS (Somatic cell score) as SCS $=\log _{10}$ SCC (Mrode and Swonson, 1996). The data obtained on teat condition score (TCS) and somatic cell count were analyzed using an SPSS statistical package (version 11.5), to obtain the mean and standard error (S.E.) values of somatic cell score. The significance of differences in measurements was tested using Duncan's Multiple Range test.

\section{Results and Discussions:}

On the basis on teat condition score (TCS) all animals were scored as normal (Gr.1), less severe (Gr.2) and severe (Gr.3) in repeated measures. The mean SCS of repeated measures (cows and buffaloes) on the basis of teat condition during the experimental period are presented in Table-1.The mean SCS of milk in group-I, group-II and group-III was ranged from $3.60 \pm 0.65$ to $4.99 \pm 0.51,4.55 \pm 0.66$ to $5.97 \pm 0.06$ and $5.75 \pm 0.05$ to $6.05 \pm 0.07$, respectively in cows and from $4.93 \pm 0.46$ to $5.72 \pm 0.02,5.37 \pm 0.45$ to $6.06 \pm 0.03$ and $5.70 \pm 0.00$ to $6.30 \pm 0.00$ in group-I, group-II and group-III buffaloes, respectively. The overall SCS in both cows and buffaloes was significantly $(\mathrm{P}<0.05)$ highest in group-III $(5.91 \pm 0.02$ and $6.09 \pm 0.35)$ followed by group-II $(5.15 \pm 0.18$ and5.85 \pm 0.09$)$ and group-I $(4.18 \pm 0.21$ and 5.31 \pm 0.112$)$. The higher mean SCS of Gr.III was might be due to infection in mammary gland, which leads the inflammation and more influx of leucocytes in milk. These findings are in collaboration with Haghkhahet al. (2009) who also reported a significant correlation between teat condition and somatic cell count and reported that injured (severe) teat have significantly higher SCC in comparison to normal teat whereas Bakken (1981) had not found significant correlation between teat lesion and SCC.

Tablel: Relationships between the teat condition scoreand SCS of milk during monitored period of lactation

\begin{tabular}{|c|c|c|c|c|c|c|}
\hline \multirow{2}{*}{$\begin{array}{c}\text { Monitored } \\
\text { periods during } \\
\text { lactations } \\
\text { (days) }\end{array}$} & Group-I & Group-II & Group-III & Group-I & Group-II & Group-III \\
\cline { 2 - 6 } & \multicolumn{5}{|c|}{ Mean SCS (log $10^{\text {SCC) of milk }}$} \\
\hline $\mathbf{1 5}$ & $4.95 \pm 0.51$ & $5.97 \pm 0.06$ & $6.00 \pm 0.08$ & $5.71^{\mathrm{c}} \pm 0.01$ & $6.04^{\mathrm{b}} \pm 0.02$ & $6.25^{\mathrm{a}} \pm 0.05$ \\
\hline $\mathbf{3 0}$ & $4.99 \pm 0.51$ & $5.01^{ \pm} \pm 0.57$ & $6.03 \pm 0.07$ & $5.57 \pm 0.27$ & $5.96 \pm 0.07$ & $5.91 \pm 0.05$ \\
\hline $\mathbf{4 5}$ & $3.92^{\mathrm{b}} \pm 0.67$ & $4.55^{\mathrm{ab}} \pm 0.66$ & $5.75^{\mathrm{a}} \pm 0.05$ & $4.93 \pm 0.46$ & $5.51 \pm 0.40$ & $5.70 \pm 0.00$ \\
\hline $\mathbf{6 0}$ & $3.60^{\mathrm{b}} \pm 0.65$ & $4.95^{\mathrm{ab}} \pm 0.57$ & $5.86^{\mathrm{a}} \pm 0.07$ & $5.02 \pm 0.41$ & $5.95 \pm 0.06$ & $6.13 \pm 0.06$ \\
\hline $\mathbf{7 5}$ & $3.95^{\mathrm{b}} \pm 0.63$ & $4.93^{\mathrm{ab}} \pm 0.56$ & $5.97^{\mathrm{a}} \pm 0.06$ & $5.49 \pm 0.38$ & $5.37 \pm 0.45$ & $5.82 \pm 0.07$ \\
\hline $\mathbf{9 0}$ & $3.96^{\mathrm{b}} \pm 0.63$ & $5.01^{\mathrm{ab}} \pm 0.57$ & $5.81^{\mathrm{a}} \pm 0.05$ & $5.07 \pm 0.38$ & $6.06 \pm 0.04$ & $6.12 \pm 0.12$ \\
\hline $\mathbf{1 0 5}$ & $3.96^{\mathrm{b}} \pm 0.63$ & $5.52^{\mathrm{a}} \pm 0.43$ & $5.76^{\mathrm{a}} \pm 0.04$ & $4.95 \pm 0.48$ & $6.06 \pm 0.03$ & $6.23 \pm 0.07$ \\
\hline $\mathbf{1 2 0}$ & $4.14^{\mathrm{b}} \pm 0.66$ & $5.22^{\mathrm{ab}} \pm 0.59$ & $6.05^{\mathrm{a}} \pm 0.07$ & $5.72^{\mathrm{c}} \pm 0.02$ & $6.04^{\mathrm{b}} \pm 0.02$ & $6.30^{\mathrm{a}} \pm 0.00$ \\
\hline Overall & $4.18^{\mathrm{c}} \pm 0.21$ & $5.15^{\mathrm{b}} \pm 0.18$ & $5.91^{\mathrm{a}} \pm 0.02$ & $5.31^{\mathrm{b}} \pm 0.12$ & $5.85^{\mathrm{a}} \pm 0.09$ & $6.09^{\mathrm{a}} \pm 0.35$ \\
\hline
\end{tabular}

Dairy bovines having with teat skin discoloured, cracked and teat end very rough had significantly higher SCC in comparison to teats with normal skin and smooth teat ends. Therefore teat condition score can be acts as an important tool to assess the health condition of udder.

\section{References:}

[1]. Bakken, G. (1981): Relationships between udder and teat morphology, mastitis and milk production in Norwegian Red cattle. Acta Agric. Scand., 31:438-444.

[2]. Bhutto, A. L., (2010): Abnormal udder shape or teat-end lesions in dairy cows might facilitate intra-mammary infections.Vet. Jour., 183(1):63-67

[3]. Haghkhah, M., Ahmadi, M. R., Gheisari, H. R. and Kadivar, A. (2011): Preliminary bacterial study on subclinical mastitis and teat condition in dairy herd around Shiraz. Turk. Journal of Veterinary and Animal Science,35(1): 1-8.

[4]. Hemling, T. C., Mein, G. A., Neijenhuis, F., Morgan, W. F., Reinemann, D. J., Hillerton, J. E., Baines, J. R., Ohnstad, I., Rasmussen, M. D., Timms, L., Britt, J. S., Farnsworth, R. and Cook, N. (2002): Evaluation of bovine teat condition in commercial 
dairy herds: 6. Teat condition - prevention and cure through teat dips. Proceedings of the 2nd Panamerican Congress on Milk Quality and Mastitis Control, RibeirãoPreto, Brazil, S02-04:13.

[5]. Hillerton, J. E. (2005): Teat Condition Scoring - An Effective Diagnostic Tool. National Mastitis Council Reg. Meeting Proc., 3743.

[6]. Hillerton, J. E., Mein, G. A., Neijenhuis, F., Morgan, W. F., Reinemann, D. J., Baines, J. R., Ohnstad, I., Rasmussen, M. D., Timms, L., Britt, J. S., Farnsworth, R., Cook, N. and Hemling, T. (2002): Evaluation of bovine teat condition in commercial dairy herds: 5. Environmental factors. Proceedings of the 2nd Panamerican Congress on Milk Quality and Mastitis Control, RibeirãoPreto, Brazil, S01-02:6.

[7]. Mein, G. A., Neijenhuis, F. and Morgan, W. F. (2001): Evaluation of bovine teat condition in commercial dairy herds: 1. Noninfectious factors. In: Proceedings of the American Association of Bovine Practitioners - National Mastitis Council International Symposium on Mastitis and Milk Quality, Vancouver, BC, Canada, 347-351.

[8]. Mrode, R.A. and Swanson, G. J. T. (1996): Genetic and statistical properties of somatic cell count and its suitability as an indirect means of reducing the incidence of mastitis in dairy cattle. Anim. Breed., Abstract 64:847-857.

[9]. Reinemann, D. J., Rasmussen, M. D., Le Mire, S., Neijenhuis, F., Mein, G. A., Hillerton, J. E., Morgan, W. F., Timms, L., Cook, N., Farnsworth, R., Baines, J. R. and Hemling, T. (2001): Evaluation of bovine teat condition in commercial dairy herds: 3. Getting the numbers right. Proceedings of the 2nd International Symposium on Mastitis and Milk Quality, NMC/AABP, Vancouver, Pages 357-361.

[10]. Taylor, V., (2006): Dairy cow teat condition scoring. Milk quality assurance program Lead/OMAFRA (ministry of agriculture food and rural affairs): Factsheet, 6-19. 